\title{
ANALISIS PENENTUAN INDIKATOR KUNCI DALAM PENGHITUNGAN INDEKS KESEJAHTERAAN MASYARAKAT KELAUTAN DAN PERIKANAN
}

\section{Analysis of The Key Indicators Determination in The Calculation of The Marine Fisheries Community Welfare Index}

\author{
*Subhechanis Saptanto, Tikyrino Kurniawan, Hertria Maharani Putri dan Tajerin \\ Balai Besar Riset Sosial Ekonomi Kelautan dan Perikanan \\ Gedung Balitbang KP I Lt. 4 \\ Jalan Pasir Putih Nomor 1 Ancol Timur, Jakarta Utara, Indonesia \\ Telp: (021) 64711583 Fax: 64700924 \\ Diterima tanggal: 30 April 2017 Diterima setelah perbaikan: 27 Mei 2017 \\ Disetujui terbit: 6 Juni 2017 \\ "email: anis_saptanto@yahoo.com
}

\begin{abstract}
ABSTRAK
Indeks Kesejahteraan Masyarakat Kelautan Perikanan (IKMKP) merupakan salah satu indeks yang secara cepat dapat mengukur tingkat kesejahteraan yang bergerak di sektor kelautan dan perikanan. Dalam indeks kesejahteraan terdapat indikator-indikator kunci yang menjadi penentu kesejahteraan masyarakat kelautan dan perikanan (KP). Tujuan dari penulisan makalah ini adalah menganalisis indikator-indikator kunci dalam penghitungan indeks kesejahteraan masyarakat kp agar dapat menghasilkan sebuah strategi baik yang bersifat pemeliharaan maupun perbaikan nilai IKMKP pada provinsi-provinsi di Indonesia. Data yang digunakan dalam penelitian ini adalah data sekunder yang bersumber dari instansi di lingkup Kementerian Kelautan dan Perikanan. Waktu penelitian dilakukan dari bulan Februari 2017 hingga April 2017. Metode pengumpulan data dilakukan dengan studi literatur dan mendatangi langsung instansi yang terkait dengan data. Metode analisis data digunakan metode data panel kausalitas Granger. Metode ini dapat digunakan untuk menganalisis indikator-indikator yang menjadi kunci untuk dilakukan perbaikan dan perawatan. Hasil penelitian menunjukkan bahwa indikator kunci di bidang sosial antara lain XS (kelembagaan usaha KUB Tangkap), $\mathrm{XS}_{4}$ (Kelembagaan usaha Garam Rakyat), $\mathrm{XS}_{5}$ (kelembagaan Pokmaswas), $\mathrm{XS}_{7}$ (masyarakat adat, tradisional dan lokal yang direvitalisasi) dan $\mathrm{XS}_{9}$ (pelaku usaha mikro yang mandiri di kawasan pesisir dan pulau-pulau kecil) dan indikator di bidang ekonomi yaitu $\mathrm{XE}_{1}$ (Nilai Tukar Nelayan), $\mathrm{XE}_{8}$ (Rata-rata pendapatan petambak garam/bulan) dan $\mathrm{XE}_{11}$ (struktur ongkos usaha perikanan). Dari indikator kunci tersebut, dapat dijadikan pedoman oleh pengambil kebijakan untuk memilih program tercepat yang dapat meningkatkan kesejahteraan masyarakat kelautan dan perikanan.
\end{abstract}

Kata Kunci: indikator kunci, indeks kesejahteraan, sektor Kelautan dan Perikanan

\section{ABSTRACT}

The marine fisheries community welfare index is one of the indexes that can rapidly measure the level of moving welfare in the marine and fisheries sector. In the index of welfare there are key indicators that determine the welfare of the marine and fisheries community. The purpose of writing this paper is to analyze the key indicators in calculating the marine and fisheries community welfare index so that it can produce a good strategy for maintenance and improvement in the provinces in Indonesia. The data used in this study is secondary data sourced from department in Ministry of Marine Affairs and Fisheries. The study was conducted from February 2017 until April 2017. The data collection method was done by literature study and went directly to the related institution with the data. Data analysis method used Granger causality data panel method. This method can be used to analyze the key indicators for improvement and maintenance. The results of the study indicate that key social indicators include XS1 (KUB/Sharing Business Cooperation Fisheries Capture), XS4 (Salt Business Institution), XS5 (institutional of Supervisor Community), XS7 (indigenous, traditional and local community revitalized) and XS9 (independent micro businessmen in the coastal and small islands area) and economic indicator such as XE1 (Fisherman Exchange Rate), XE8 (Average salt farm income per month) and XE11 (fishery cost structure). From these key indicators, it can be used as a guide by policy makers to choose the fastest program that can improve the welfare of marine and fishery communities.

Keywords: key indicators, welfare index, marine and fisheries sector 


\section{PENDAHULUAN}

\begin{tabular}{lrrr}
\multicolumn{2}{c}{ Pembangunan nasional } & seharusnya \\
diarahkan untuk memacu & pemerataan \\
pembangunan dan hasil-hasilnya & dapat \\
meningkatkan kesejahteraan rakyat. & Selain
\end{tabular} itu, pembangunan nasional bertujuan untuk mewujudkan suatu masyarakat adil dan makmur yang merata baik materil dan spiritual. Pembangunan juga harus berdasarkan Pancasila dan UndangUndang Dasar 1945 dalam Negara Kesatuan Republik Indonesia yang merdeka, berdaulat, bersatu, dan berkedaulatan rakyat dalam suasana perikehidupan bangsa yang aman, tentram, tertib, dan dinamis (Sutaryo et al., 2015). Menurut Todaro dan Smith (2003), pembangunan ekonomi pada hakekatnya merupakan suatu proses perbaikan yang berkesinambungan dari suatu masyarakat atau sistem sosial secara keseluruhan menuju kepada kehidupan yang lebih baik, dimana proses pembangunan bertujuan untuk meningkatkan taraf hidup kesejahteraan rakyat serta harkat dan martabat manusia yang meliputi peningkatan berbagai barang kebutuhan pokok, peningkatan standar hidup serta perluasan pilihan ekonomi dan sosial bagi seluruh masyarakat.

Menurut Satria (2002), permasalahan yang berkaitan dengan masyarakat pesisir, sangat erat hubungannya dengan masalah masyarakat nelayan karena sebagian besar penduduknya pada umumnya memiliki mata pencaharian sebagai nelayan. Definisi masyarakat pesisir menurut Nikijuluw (2001) sebagai kelompok orang yang tinggal di daerah pesisir dan sumber kehidupan perekonomiannya bergantung secara langsung pada pemanfaatan sumberdaya laut dan pesisir. Beberapa isu krusial terkait kesejahteraan masyarakat kelautan dan perikanan masih terlihat secara nyata di hadapan kita, yakni: kesenjangan sosial ekonomi antar kawasan, kemiskinan masyarakat di wilayah pesisir dan pulau-pulau kecil, penggunaan indikator nilai tukar pelaku utama (nelayan dan pembudidaya ikan).

Kesejahteraan merupakan bagian dari 3 pilar yang menjadi misi Kementerian Kelautan dan Perikanan (KKP), selain kedaulatan dan keberlanjutan. Artinya, kesejahteraan merupakan aspek penting yang harus dicapai oleh pemerintah dalam hal ini KKP dalam hal kesejahteraan masyarakat kelautan dan perikanan. Kesejahteraan (Prosperity) yang dimaksud yaitu mewujudkan masyarakat kelautan dan perikanan yang sejahtera, maju, mandiri, serta berkepribadian dalam kebudayaan. Hal ini tercantum dalam PerMen KP No. 45 tahun 2015 tentang Perubahan Atas Peraturan Menteri Kelautan dan Perikanan Republik Indonesia Nomor 25/Permen-Kp/2015 tentang Rencana Strategis Kementerian Kelautan dan Perikanan Tahun 2015-2019 (KKP, 2015). IKU kesejahteraan masyarakat ini menempati urutan teratas dalam peta strategi KKP dari sisi stakeholder perspektif. KKP juga telah melakukan pengukuran kesejahteraan masyarakat kelautan dan perikanan yang dinamakan Indeks Kesejahteraan Masyarakat Kelautan dan Perikanan (IKMKP). Indeks kesejahteraan masyarakat kelautan dan perikanan berasal dari 2 dimensi yakni dimensi ekonomi dan sosial yang terbagi menjadi beberapa indikatorindikator.

Namun, jika hanya sebatas nilai indeks saja, maka pemerintah akan kesulitan menyusun program yang sekiranya dapat cepat meningkatkan nilai kesejahtetaan masyarat KP. Untuk itu penting dilakukan kajian untuk melihat indikator yang akan secara cepat meningkatkan nilai kesejahteraan masyarakat $\mathrm{KP}$ jika pemerintah segera melakukan sentuhan program di indikator tersebut. Indikator kunci tersebut dapat dijadikan sebagai strategi peningkatan kesejahteraan yang efektif dan efisien. Tujuan dari penulisan makalah ini adalah untuk menentukan indikator kunci yang paling berpengaruh dalam penghitungan indeks kesejahteraan masyarakat kelautan dan perikanan sehingga dapat meningkatkan nilai IKMKP .

\section{METODOLOGI}

\section{Kerangka Pemikiran}

Kesejahteraan Masyarakat dalam paradigma pembangunan ekonomi, perubahan kesejahteraan masyarakat merupakan bagian yang tidak terpisahkan. Hal ini dikarenakan pembangunan ekonomi dikatakan berhasil jika tingkat kesejahteraan masyarakat semakin baik. Keberhasilan pembangunan ekonomi tanpa menyertakan peningkatan kesejahteraan masyarakat akan mengakibatkan kesenjangan dan ketimpangan dalam kehidupan masyarakat. Kesejahteraan masyarakat adalah suatu kondisi yang memperlihatkan tentang keadaan kehidupan masyarakat yang dapat dilihat dari standar kehidupan masyarakat (Badrudin, 2012). 
Ada beberapa konsep kesejahteraan dari para ahli. Menurut Nasikun (1996) kesejahteraan merupakan konsep martabat manusia yang dapat dilihat dari empat indikator yaitu: (1) Rasa aman (security); (2) Kesejahteraan (welfare); (3) Kebebasan (freedom), dan; (4) Jati diri (Identity). Sedangkan menurut Badan Pusat Statistik Indonesia (2000) menerangkan bahwa guna melihat tingkat kesejahteraan rumah tangga suatu wilayah ada beberapa indikator yang dapat dijadikan ukuran yakni: (1) Tingkat pendapatan keluarga; (2) Komposisi pengeluaran rumah tangga dengan membandingkan pengeluaran untuk pangan dengan non-pangan; (3) Tingkat pendidikan keluarga; (4) Tingkat kesehatan keluarga, dan; (5) Kondisi perumahan serta fasilitas yang dimiliki dalam rumah tangga. Menurut Kolle (1974) dalam Bintarto (1989), kesejahteraan dapat diukur dari beberapa aspek kehidupan: (1) Dengan melihat kualitas hidup dari segi materi, seperti kualitas rumah, bahan pangan dan sebagainya; (2) Dengan melihat kualitas hidup dari segi fisik, seperti kesehatan tubuh, lingkungan alam, dan sebagainya; (3) Dengan melihat kualitas hidup dari segi mental, seperti fasilitas pendidikan, lingkungan budaya, dan sebagainya, dan: (4) Dengan melihat kualitas hidup dari segi spiritual, seperti moral, etika, keserasian penyesuaian, dan sebagainya. Todaro dan Smith (2003) mengemukakan bahwa kesejahteraan masyarakat menengah ke bawah dapat direpresentasikan dari tingkat hidup masyarakat. Tingkat hidup masyarakat ditandai dengan terentaskannya dari kemiskinan, tingkat kesehatan yang lebih baik, perolehan tingkat pendidikan yang lebih tinggi, dan tingkat produktivitas masyarakat.

Negara sejahtera merupakan sebuah konsep yang mewajibkan negara untuk melakukan pelayanan atas kebutuhan dasar masyarakat, termasuk sandang, pangan, pemberian bantuan pendidikan dan kesehatan terhadap warga negara secara cuma-cuma tergolong yang dipentingkan. Sedangkan kelompok lain Vilhelm Aubet, meletakkan sejahtera diartikan sebagai hak-hak politik atas terpenuhinya kebutuhan-kebutuhan dasar masyarakat baik dalam arti kebutuhan ekonomi, politik, sosial dan budaya. Negara dalam konteks ini, dibebani selain kewajiban untuk memenuhi kebutuhan masyarakat, juga masyarakat memilki hak untuk melakukan komplain ketika pemerintah tidak mampu menunaikan kewajiban-kewajibannya secara pantas dan benar. Sedangkan Lawrence Friedman dan Anwaral
Yahin, menempatkan konsep negara sejahtera ditekankan pada peran dan fungsi hukum yang mengatur kewajiban-kewajiban negara dalam memberikan pelayanan pada terpenuhinya kebutuhan-kebutuhan dasar masyarakat (Mishra, 2000)

Kesejahteraan juga merupakan salah satu dari 3 pilar yang menjadi misi Kementerian Kelautan dan Perikanan (KKP), selain kedaulatan dan keberlanjutan. Kesejahteraan (Prosperity), yakni mewujudkan masyarakat kelautan dan perikanan yang sejahtera, maju, mandiri, serta berkepribadian dalam kebudayaan. Kesejahteraan diartikan bahwa pengelolaan sumber daya kelautan dan perikanan adalah untuk sebesar-besarnya kemakmuran rakyat. Dalam kaitan ini, KKP senantiasa memberikan perhatian penuh terhadap seluruh stakeholders kelautan dan perikanan, yakni nelayan, pembudidaya ikan, pengolah/pemasar hasil perikanan, petambak garam, dan masyarakat kelautan dan perikanan lainnya (KKP, 2015).

Salah satu Indikator Kinerja Utama (IKU) KKP atas penjabaran misi "kesejahteraan" adalah terwujudnya kesejahteraan masyarakat KP yang ditargetkan dari 40,1 pada tahun 2015 menjadi 51 pada tahun 2019. Hal ini secara eksplisit tercantum dalam PerMen KP No. 45 tahun 2015 tentang Perubahan Atas Peraturan Menteri Kelautan dan Perikanan Republik Indonesia Nomor 25/PermenKP/2015 tentang Rencana Strategis Kementerian Kelautan dan Perikanan Tahun 2015-2019. IKU kesejahteraan masyarakat ini menempati urutan teratas dalam peta strategi KKP dari sisi stakeholder perspektif. Oleh karena itu pengukuran kesejahteraan masyarakat kelautan dan perikanan secara periodik perlu dilakukan guna melihat perkembangannya.

\section{Jenis dan Sumber Data}

Jenis data yang digunakan dalam penelitian ini lebih banyak menggunakan data sekunder yang berasal dari seluruh Direktorat Jenderal (Ditjen) lingkup Kementerian Kelautan dan Perikanan. Data-data yang digunakan dalam penelitian terbagi menjadi data sosial dan ekonomi yang ditabulasi dan dianalisis untuk menghasilkan indikator yang diinginkan. Data-data yang digunakan tersebut ditampilkan dalam Tabel 1.

\section{Lokasi dan Waktu Penelitian}

Penelitian ini dilakukan dari bulan Februari 2017 - April 2017 bertempat di DKI Jakarta. 
Tabel 1. Jenis dan Sumber Data yang Digunakan Dalam Penelitian.

Table 1. Types and Sources of Data Used In Research.

\begin{tabular}{|c|c|c|c|}
\hline No & $\begin{array}{l}\text { Variabel/ } \\
\text { Variable }\end{array}$ & $\begin{array}{l}\text { Deskripsi/ } \\
\text { Description }\end{array}$ & $\begin{array}{c}\text { Sumber Data } \\
\text { Data Source }\end{array}$ \\
\hline 1 & $\mathrm{XS}_{1}$ & $\begin{array}{l}\text { Jumlah penumbuhan dan pengembangan kelembagaan } \\
\text { usaha perikanan tangkap (KUB)/ Number of growth and } \\
\text { institutional development of capture fisheries business }\end{array}$ & BRSDMKP \\
\hline 2 & $\mathrm{XS}_{2}$ & $\begin{array}{l}\text { Jumlah penumbuhan dan pengembangan kelembagaan } \\
\text { usaha budidaya ikan (Pokdakan)/ Number of growth and } \\
\text { development of fish farmer institutional business }\end{array}$ & BRSDMKP \\
\hline 3 & $\mathrm{XS}_{3}$ & $\begin{array}{l}\text { Jumlah penumbuhan dan pengembangan kelembagaan } \\
\text { pemasaran perikanan (Poklasar)/ Number of growth and } \\
\text { development of fisheries market agent institutional }\end{array}$ & BRSDMKP \\
\hline 4 & $\mathrm{XS}_{4}$ & $\begin{array}{l}\text { Jumlah penumbuhan dan pengembangan kelembagaan } \\
\text { usaha garam rakyat (Kugar)/ Number of growth and } \\
\text { development of community salt institutional }\end{array}$ & BRSDMKP \\
\hline 5 & $\mathrm{XS}_{5}$ & $\begin{array}{l}\text { Jumlah penumbuhan dan pengembangan kelembagaan } \\
\text { kelompok masyarakat pengawas (Pokmaswas)/Number } \\
\text { of growth and institutional development of supervisory } \\
\text { community groups }\end{array}$ & BRSDMKP \\
\hline 6 & $\mathrm{XS}_{6}$ & $\begin{array}{l}\text { Jumlah kelembagaan usaha yang terpantau dan } \\
\text { terevaluasi/ yang mendapatkan bantuan fasilitas/ } \\
\text { Number of monitored and evaluated business institutional } \\
\text { institutions that receive facility assistance }\end{array}$ & $\begin{array}{l}\text { DJ-PT, DJ-PB, } \\
\text { DJ-PDSPKP, } \\
\text { DJ-PRL, } \\
\text { DJ-PSDKP }\end{array}$ \\
\hline 7 & $\mathrm{XS}_{7}$ & $\begin{array}{l}\text { Jumlah masyarakat adat, tradisional dan lokal yang } \\
\text { direvitalisasi/Number of indigenous, traditional and local } \\
\text { communities being revitalized }\end{array}$ & DJ-PRL \\
\hline 8 & $\mathrm{XS}_{8}$ & $\begin{array}{l}\text { Jumlah Lembaga Ketahanan Masyarakat pesisir yang } \\
\text { terfasilitasi permodalannya di kawasan pesisir dan pulau- } \\
\text { pulau kecil/Number of Coastal Community Resilience } \\
\text { Institutions facilitated by capital in coastal areas and small } \\
\text { islands }\end{array}$ & DJ-PRL \\
\hline 9 & $\mathrm{XS}_{9}$ & $\begin{array}{l}\text { Jumlah pelaku usaha mikro yang mandiri di kawasan } \\
\text { pesisir dan pulau-pulau kecil/Number of independent micro } \\
\text { business actors in coastal areas and small islands }\end{array}$ & DJ-PRL \\
\hline 10 & $\mathrm{XS}_{10}$ & $\begin{array}{l}\text { Jumlah kelompok pelaku utama/usaha yang meningkat } \\
\text { kelasnya dari jumlah kelompok pelaku utama/usaha } \\
\text { yang disuluh/Number of main actors/business groups } \\
\text { that increase in class from the number of main actors / } \\
\text { businesses that are embedded }\end{array}$ & BRSDMKP \\
\hline 11 & $\mathrm{XS}_{11}$ & $\begin{array}{l}\text { Jumlah kelompok yang disuluh mendukung tata kelola } \\
\text { pemanfaatan sumber daya KP yang berdaya saing dan } \\
\text { berkelanjutan/Number of clustered groups supports the } \\
\text { governance of competitive and sustainable marine and } \\
\text { fisheries resource utilization }\end{array}$ & BRSDMKP \\
\hline 12 & $\mathrm{XE}_{1}$ & Nilai Tukar Nelayan (NTN)/Fisherman term of trade & DJ-PT \\
\hline 13 & $\mathrm{XE}_{2}$ & Nilai Tukar Pembudidaya (NTPi)/Fish farmer term of trade & DJ-PB \\
\hline 14 & $\mathrm{XE}_{3}$ & $\begin{array}{l}\text { Nilai Tukar Pengolah (NTPo)/Fish processing actors term } \\
\text { of trade }\end{array}$ & DJ-PDSPKP \\
\hline 15 & $\mathrm{XE}_{4}$ & $\begin{array}{l}\text { Nilai Tukar Petambak Garam (NTPG)/Salt farmer term of } \\
\text { trade }\end{array}$ & DJ-PRL \\
\hline
\end{tabular}


Lanjutan Tabel 1/Continue Table 1

\begin{tabular}{|c|c|c|c|}
\hline No & $\begin{array}{l}\text { Variabel/ } \\
\text { Variable }\end{array}$ & $\begin{array}{l}\text { Deskripsi/ } \\
\text { Description }\end{array}$ & $\begin{array}{l}\text { Sumber Data/ } \\
\text { Data Source }\end{array}$ \\
\hline 16 & $\mathrm{XE}_{5}$ & $\begin{array}{l}\text { Rata-rata pendapatan nelayan(Rp/bulan)/Average of } \\
\text { Fisher income(IDR/month) }\end{array}$ & DJ-PT \\
\hline 17 & $\mathrm{XE}_{6}$ & $\begin{array}{l}\text { Rata-rata pendapatan pembudidaya(Rp/bulan)/Average of } \\
\text { fish farmer (IDR/month) }\end{array}$ & DJ-PB \\
\hline 18 & $X E_{7}$ & $\begin{array}{l}\text { Rata-rata pendapatan pengolah perikanan (Rp/bulan)/ } \\
\text { Average of fish processing actor (IDR/month) }\end{array}$ & DJ-PDSPKP \\
\hline 19 & $\mathrm{XE}_{8}$ & $\begin{array}{l}\text { Rata-rata pendapatan petambak garam (Rp/bulan)/ } \\
\text { Average of salt farmer (IDR/month) }\end{array}$ & DJ-PRL \\
\hline 20 & $\mathrm{XE}_{9}$ & $\begin{array}{l}\text { Jumlah kawasan wisata bahari yang dikembangkan/ } \\
\text { Number of marine tourism areas developed }\end{array}$ & DJ-PRL \\
\hline 21 & $X E_{10}$ & $\begin{array}{l}\text { Proporsi pengeluaran pangan terhadap total pendapatan/ } \\
\text { The proportion of food expenditure on total income }\end{array}$ & BPS: Susenas \\
\hline 22 & $X E_{11}$ & $\begin{array}{l}\text { Struktur ongkos usaha perikanan/The cost structure of } \\
\text { fisheries business }\end{array}$ & BRSDMKP \\
\hline
\end{tabular}

\section{Metode Analisis Data}

\section{Penentuan Indikator Kunci/Leading Indicator}

Penentuan indikator kunci sangat penting dalam rangka menentukan indikator-indikator mana yang paling berpengaruh baik dari sisi dimensi sosial maupun dimensi ekonomi. Ada berbagai cara dalam penentuan leading indikator, salah satu diantaranya dengan menggunakan Metode Data Panel Kausalitas Granger. Menurut definisinya data panel (panel pooled data) sendiri merupakan gabungan data cross section dan series. Dengan kata lain, data panel merupakan data dari beberapa individu sama yang diamati dalam kurun waktu tertentu. Jika kita memiliki T periode waktu $(\mathrm{t}=1,2, \ldots, \mathrm{T})$ dan $\mathrm{N}$ jumlah individu $(\mathrm{i}=1,2, \ldots, \mathrm{N})$, maka dengan data panel kita akan memiliki total unit observasi sebanyak NT. Sedangkan kausalitas Granger bertujuan untuk mengetahui apakah variabel satu dipengaruhi oleh variabel lainnya (Susanto dan Laksana, 2013).

\section{Indikator Kunci Dimensi Sosial}

Pada dimensi sosial terdapat 11 indikator, sehingga dibentuk persamaan regresi berdasarkan data panel kausalitas Granger sebagai berikut :

$$
\begin{aligned}
X S 1_{i t}= & \sum_{i=1}^{n} a_{i} X S 2_{i t}+\sum_{i=1}^{n} b_{i} X S 3_{i t}+\sum_{i=1}^{n} c_{i} X S 4_{i t}+\sum_{i=1}^{n} d_{i} X S 5_{i t}+\sum_{i=1}^{n} e_{i} X S 6_{i t}+\sum_{i=1}^{n} f_{i} X S 7_{i t}+\sum_{i=1}^{n} g_{i} X S 8_{i t} \\
& +\sum_{i=1}^{n} h_{i} X S 9_{i t}+\sum_{i=1}^{n} i_{i} X S 10_{i t}+\sum_{i=1}^{n} j_{i} X S 11_{i t} \\
X S 11_{i t}= & \sum_{i=1}^{n} a_{i} X S 1_{i t}+\sum_{i=1}^{n} b_{i} X S 2_{i t}+\sum_{i=1}^{n} c_{i} X S 3_{i t}+\sum_{i=1}^{n} d_{i} X S 4_{i t}+\sum_{i=1}^{n} e_{i} X S 5_{i t}+\sum_{i=1}^{n} f_{i} X S 6_{i t}+\sum_{i=1}^{n} g_{i} X S 7_{i t} \\
& +\sum_{i=1}^{n} h_{i} X S 8_{i t}+\sum_{i=1}^{n} i_{i} X S 9_{i t}+\sum_{i=1}^{n} j_{i} X S 10_{i t}
\end{aligned}
$$

Dimana/Where :

XS1,..,XS11.: Indikator-indikator pada dimensi sosial/ Indicator of social dimension

t $\quad:$ Tahun/ Years

i : Provinsi/ Province

$a, b, \ldots j:$ : Koefisien regresi/ Coefficient of regression

\section{Indikator Kunci Dimensi Ekonomi}

Dengan cara yang hampir sama dapat dibentuk persamaan kausalitas Granger untuk dimensi ekonomi. Pada dimensi ekonomi terdapat 11 indikator, sehingga dibentuk persamaan regresi berdasarkan data panel kausalitas granger sebagai berikut : 


$$
\begin{aligned}
X E 1_{i t}= & \sum_{i=1}^{n} a_{i} X E 2_{i t}+\sum_{i=1}^{n} b_{i} X E 3_{i t}+\sum_{i=1}^{n} c_{i} X E 4_{i t}+\sum_{i=1}^{n} d_{i} X E 5_{i t}+\sum_{i=1}^{n} e_{i} X E 6_{i t}+\sum_{i=1}^{n} f_{i} X E 7_{i t} \\
& +\sum_{i=1}^{n} g_{i} X E 8_{i t}+\sum_{i=1}^{n} h_{i} X E 9_{i t}+\sum_{i=1}^{n} i_{i} X E 10_{i t}+\sum_{i=1}^{n} j_{i} X E 11_{i t} \\
X E 11_{i t}= & \sum_{i=1}^{n} a_{i} X E 1_{i t}+\sum_{i=1}^{n} b_{i} X E 2_{i t}+\sum_{i=1}^{n} c_{i} X E 3_{i t}+\sum_{i=1}^{n} d_{i} X E 4_{i t}+\sum_{i=1}^{n} e_{i} X E 5_{i t}+\sum_{i=1}^{n} f_{i} X E 6_{i t} \\
& +\sum_{i=1}^{n} g_{i} X E 7_{i t}+\sum_{i=1}^{n} h_{i} X E 8_{i t}+\sum_{i=1}^{n} i_{i} X E 9_{i t}+\sum_{i=1}^{n} j_{i} X E 10_{i t}
\end{aligned}
$$

Dimana/Where :

$\begin{array}{ll}\text { XE1,..., XE11 } & \begin{array}{l}\text { : Indikator-indikator pada dimensi } \\ \text { ekonomi/ Indicator of economic } \\ \text { dimension }\end{array} \\ \mathrm{t} & : \text { Tahun/ Year } \\ \mathrm{i} & : \text { Provinsi// Province } \\ \mathrm{a}, \mathrm{b}, \ldots \mathrm{j} & \text { : Koefisien regresi/ coefficient of } \\ & \text { regression }\end{array}$

Selanjutnya dengan menggunakan analisis regresi dianalisis data panel di atas dengan menggunakan software EVIEWS. Variabel-variabel yang saling mempengaruhi secara signifikan (Prob < 0,05) dikelompokkan ke dalam matriks. Sehingga diketahui variabel-variabel yang paling berpengaruh.

\section{HASIL DAN PEMBAHASAN}

\section{Strategi Peningkatan Nilai IKMKP Berbasis Program KKP}

Nilai IKMKP yang diperoleh masing-masing daerah cukup bervariasi. Terdapat daerah yang sudah memiliki tingkat kesejahteraan masyarakat kelautan dan perikanan yang cukup baik, tetapi ada pula daerah yang masih rendah tingkat kesejehteraan masyarakat KP nya. Daerah-daerah yang memiliki tingkat kesejahteraan yang sudah cukup baik (>50) maka daerah tersebut tentunya harus mempertahankan dengan mengelola aspekaspek yang ada baik pada dimensi ekonomi maupun pada dimensi sosial. Langkah strategi yang diterapkan untuk daerah yang memiliki nilai IKMKP yang cukup baik adalah strategi maintenance atau pengelolaan dalam rangka mempertahankan nilai. Jika tidak dilakukan strategi maintenance, maka potensi penurunan nilai akan semakin besar di tahun berikutnya. Sedangkan untuk daerah-daerah yang memiliki nilai IKMKP yang masih rendah $(\leq 50)$, langkah yang harus dilakukan adalah improvement atau perbaikan baik di dimensi sosial maupun ekonomi terutama pada indikatorindikator yang banyak berpengaruh terhadap nilai IKMKP (lead indicator). Adapun nilai IKMKP, strategi peningkatan IKMKP dan Program KKP yang harus didorong per provinsi, dapat dilihat pada Tabel 2.

Berdasarkan analisis kausalitas Granger dengan menggunakan data panel, indikator yang berpengaruh dari dimensi sosial adalah:

1. Indikator XS1 (penumbuhan dan pengembangan kelembagaan usaha perikanan tangkap atau KUB);

2. Indikator XS4 (penumbuhan dan pengembangan kelembagaan usaha garam rakyat atau KUGAR);

3. Indikator XS5 (penumbuhan dan pengembangan kelembagaan kelompok masyarakat pengawas/ Pokmaswas);

4. Indikator XS7 (masyarakat adat, tradisional dan lokal yang direvitalisasi); dan

5. Indikator XS9 (pelaku usaha mikro yang mandiri di kawasan pesisir dan pulau-pulau kecil).

Sedangkan untuk dimensi ekonomi, lead indicator-nya adalah:

1. Indikator XE1 (Nilai Tukar Nelayan/NTN);

2. Indikator XE8 (Rata-rata pendapatan petambak garam/bulan); dan

3. Indikator XE11 (Struktur ongkos usaha perikanan). 
Tabel 2. Nilai IKMKP, Strategi Peningkatan IKMKP dan Program KKP yang Harus Ditingkatkan Berdasarkan Provinsi.

Table 2. Value of IKMKP, IKMKP Improvement Strategy and MMF Program Should Be Improved by Province.

\begin{tabular}{|c|c|c|c|c|c|c|c|c|c|c|c|}
\hline \multirow{2}{*}{ No } & \multirow{2}{*}{ Provinsi/Province } & \multirow{2}{*}{$\begin{array}{l}\text { IKMKP } \\
2016\end{array}$} & \multirow{2}{*}{$\begin{array}{c}\text { Strategi } \\
\text { Peningkatan } \\
\text { IKMKPI IKMKP } \\
\text { Improvement } \\
\text { Strategy }\end{array}$} & \multicolumn{8}{|c|}{$\begin{array}{c}\text { Program KKP yang Harus Ditingkatkan } \\
\text { berdasarkan Indikator IKMKPI MMF Program } \\
\text { Should Be Improved based on IKMKP Indicators }\end{array}$} \\
\hline & & & & $x_{s_{1}}$ & $\mathrm{XS}_{4}$ & $\mathrm{XS}_{5}$ & $\mathrm{XS}_{7}$ & $\mathrm{XS}_{9}$ & $X E_{1}$ & $\mathrm{XE}_{8}$ & $X E_{11}$ \\
\hline 1 & Aceh & 71.94 & maintenance & $\sqrt{ }$ & & & & $\sqrt{ }$ & & & $\sqrt{ }$ \\
\hline 2 & $\begin{array}{l}\text { Sumatera Utara/ } \\
\text { North Sumatera }\end{array}$ & 3.94 & improvement & $\sqrt{ }$ & & $\sqrt{ }$ & & & & & $\sqrt{ }$ \\
\hline 3 & $\begin{array}{l}\text { Sumatera Barat/ West } \\
\text { Sumatera }\end{array}$ & 60.04 & maintenance & & & & & $\sqrt{ }$ & & & $\sqrt{ }$ \\
\hline 4 & Riau & 38.08 & improvement & $\sqrt{ }$ & & & & & $\sqrt{ }$ & & $\sqrt{ }$ \\
\hline 5 & Jambi & 16.46 & improvement & $\sqrt{ }$ & & & & & $\sqrt{ }$ & & $\sqrt{ }$ \\
\hline 6 & $\begin{array}{l}\text { Sumatera Selatan/ } \\
\text { South Sumatera }\end{array}$ & 39.76 & improvement & $\sqrt{ }$ & & $\sqrt{ }$ & & & & & $\sqrt{ }$ \\
\hline 7 & Bengkulu & 18.79 & improvement & $\sqrt{ }$ & & & & & & & $\sqrt{ }$ \\
\hline 8 & Lampung & 25.13 & improvement & $\sqrt{ }$ & & & & & & & $\sqrt{ }$ \\
\hline 9 & $\begin{array}{l}\text { Kepulauan Bangka } \\
\text { Belitung }\end{array}$ & 38.36 & improvement & $\sqrt{ }$ & & $\sqrt{ }$ & & & & & $\sqrt{ }$ \\
\hline 10 & Kepulauan Riau & 41.64 & improvement & $\sqrt{ }$ & & & & & $\sqrt{ }$ & & $\sqrt{ }$ \\
\hline 11 & DKI Jakarta & 54.44 & improvement & $\sqrt{ }$ & & & & & & & $\sqrt{ }$ \\
\hline 12 & $\begin{array}{l}\text { Jawa Barat/ West } \\
\text { Java }\end{array}$ & 89.71 & maintenance & & $\sqrt{ }$ & & & $\sqrt{ }$ & $\sqrt{ }$ & $\sqrt{ }$ & $\sqrt{ }$ \\
\hline 13 & $\begin{array}{l}\text { Jawa Tengah/ Center } \\
\text { of Java }\end{array}$ & 44.02 & improvement & $\sqrt{ }$ & $\sqrt{ }$ & $\sqrt{ }$ & & & $\sqrt{ }$ & $\sqrt{ }$ & $\sqrt{ }$ \\
\hline 14 & D I Yogyakarta & 38.84 & improvement & $\sqrt{ }$ & & & & & $\sqrt{ }$ & & $\sqrt{ }$ \\
\hline 15 & $\begin{array}{l}\text { Jawa Timur/ East } \\
\text { Java }\end{array}$ & 67.49 & maintenance & & $\sqrt{ }$ & $\sqrt{ }$ & $\sqrt{ }$ & $\sqrt{ }$ & $\sqrt{ }$ & $\sqrt{ }$ & $\sqrt{ }$ \\
\hline 16 & Banten & 29.24 & improvement & & & $\sqrt{ }$ & & & $\sqrt{ }$ & & $\sqrt{ }$ \\
\hline 17 & Bali & 66.02 & improvement & & & & $\sqrt{ }$ & & $\sqrt{ }$ & & $\sqrt{ }$ \\
\hline 18 & $\begin{array}{l}\text { Nusa Tenggara Barat/ } \\
\text { West Nusatenggara }\end{array}$ & 100.00 & maintenance & & & $\sqrt{ }$ & & $\sqrt{ }$ & & & $\sqrt{ }$ \\
\hline 19 & $\begin{array}{l}\text { Nusa Tenggara Timur/ } \\
\text { East Nusatenggara }\end{array}$ & 82.18 & maintenance & & & & & $\sqrt{ }$ & & & $\sqrt{ }$ \\
\hline 20 & $\begin{array}{l}\text { Kalimantan Barat/ } \\
\text { West Kalimantan }\end{array}$ & 69.98 & maintenance & & & & & $\sqrt{ }$ & & & $\sqrt{ }$ \\
\hline 21 & $\begin{array}{l}\text { Kalimantan Tengah/ } \\
\text { Center of Kalimantan }\end{array}$ & 0.00 & improvement & $\sqrt{ }$ & & $\sqrt{ }$ & & & $\sqrt{ }$ & & $\sqrt{ }$ \\
\hline 22 & $\begin{array}{l}\text { Kalimantan Selatan/ } \\
\text { South Kalimantan }\end{array}$ & 43.16 & improvement & & & $\sqrt{ }$ & & & $\sqrt{ }$ & & $\sqrt{ }$ \\
\hline 23 & $\begin{array}{l}\text { Kalimantan Timur/ } \\
\text { East Kalimantan }\end{array}$ & 12.33 & improvement & $\sqrt{ }$ & & & & & & & $\sqrt{ }$ \\
\hline 24 & $\begin{array}{l}\text { Kalimantan Utara/ } \\
\text { North Kalimantan }\end{array}$ & 7.33 & improvement & $\sqrt{ }$ & & & & & & & $\sqrt{ }$ \\
\hline 25 & $\begin{array}{l}\text { Sulawesi Utara/ North } \\
\text { Sulawesi }\end{array}$ & 44.32 & improvement & $\sqrt{ }$ & & & & & & & $\sqrt{ }$ \\
\hline
\end{tabular}


Lanjutan Tabel 2/Continue Table 2

\begin{tabular}{|c|c|c|c|c|c|c|c|c|c|c|c|}
\hline \multirow{2}{*}{ No } & \multirow{2}{*}{ Provinsi/Province } & \multirow{2}{*}{$\begin{array}{l}\text { IKMKP } \\
2016\end{array}$} & \multirow{2}{*}{$\begin{array}{c}\text { Strategi } \\
\text { Peningkatan } \\
\text { IKMKPI IKMKP } \\
\text { Improvement } \\
\text { Strategy }\end{array}$} & \multicolumn{8}{|c|}{$\begin{array}{c}\text { Program KKP yang Harus Ditingkatkan } \\
\text { berdasarkan Indikator IKMKPI MMF Program } \\
\text { Should Be Improved based on IKMKP Indicators }\end{array}$} \\
\hline & & & & $X S_{1}$ & $\mathrm{XS}_{4}$ & $\mathrm{XS}_{5}$ & $\mathrm{XS}_{7}$ & $\mathrm{XS}_{9}$ & $X E_{1}$ & $X E_{8}$ & $X E_{11}$ \\
\hline 26 & $\begin{array}{l}\text { Sulawesi Tengah/ } \\
\text { Center of Sulawesi }\end{array}$ & 47.77 & improvement & $\sqrt{ }$ & & & & & & & $\sqrt{ }$ \\
\hline 27 & $\begin{array}{l}\text { Sulawesi Selatan/ } \\
\text { South Sulawesi }\end{array}$ & 81.63 & maintenance & & & & $\sqrt{ }$ & $\sqrt{ }$ & & & $\sqrt{ }$ \\
\hline 28 & $\begin{array}{l}\text { Sulawesi Tenggara/ } \\
\text { South East Sulawesi }\end{array}$ & 95.50 & maintenance & & & & & & $\sqrt{ }$ & $\sqrt{ }$ & $\sqrt{ }$ \\
\hline 29 & Gorontalo & 87.65 & maintenance & & & & & $\sqrt{ }$ & & & $\sqrt{ }$ \\
\hline 30 & $\begin{array}{l}\text { Sulawesi Barat/ West } \\
\text { Sulawesi }\end{array}$ & 63.49 & maintenance & & & & & $\sqrt{ }$ & & & $\sqrt{ }$ \\
\hline 31 & Maluku & 95.69 & maintenance & & & & & $\sqrt{ }$ & & & $\sqrt{ }$ \\
\hline 32 & $\begin{array}{l}\text { Maluku Utara/ North } \\
\text { Mollucas }\end{array}$ & 16.62 & improvement & $\sqrt{ }$ & & $\sqrt{ }$ & & & & & $\sqrt{ }$ \\
\hline 33 & Papua & 22.14 & improvement & $\sqrt{ }$ & & & & & & & $\sqrt{ }$ \\
\hline \multirow[t]{2}{*}{34} & $\begin{array}{l}\text { Papua Barat/ West } \\
\text { Papua }\end{array}$ & 29.38 & improvement & & & & & & $\sqrt{ }$ & & $\sqrt{ }$ \\
\hline & Jumlah/Total & & & 19 & 3 & 10 & 3 & 11 & 13 & 4 & 34 \\
\hline
\end{tabular}

Sumber : Data Primer, Diolah (2017)/Source : Primary Data, processed (2017)

Khusus untuk indikator yang berkaitan dengan garam, indikator hanya akan banyak mempengaruhi di kawasan yang memang terdapat potensi produk garam. Indikator kunci tersebut menjadi indikator yang harus diperhatikan oleh semua provinsi dengan merujuk pada nilai yang dimiliki masing-masing provinsi (Tabel 2).

Dari tabel tersebut dapat terlihat indikator dalam IKMPKP yang harus banyak disoroti di seluruh Provinsi adalah terkait dengan struktur ongkos usaha perikanan khususnya dalam hal ini adalah perikanan tangkap. Tingginya harga bahan bakar minyak untuk operasional dan biaya-biaya operasional lainnya menjadikan keuntungan yang diperoleh nelayan terutama nelayan buruh tidak maksimal. Pemerintah harus dapat memfokuskan kebijakannya untuk menekan struktur ongkos usaha perikanan sehingga tidak menggerus laba yang seharusnya diperoleh. Begitu pula dengan NTN yang kurang baik di 13 Provinsi. NTN hingga saat ini masih menjadi patokan bagi seluruh provinsi di Indonesia untuk mengukur tingkat kesejahteraan masyarakat KP. Sejauh mana kemampuan tukar hasil tangkapan/produksi nelayan dengan barang dan jasa yang diperlukan untuk keperluan usaha penangkapan ikan dan konsumsi pangan dan non pangan rumah tangga nelayan. Programprogram pemerintah juga seharusnya difokuskan untuk meningkatkan NTN nelayan sehingga nelayan mampu memenuhi kebutuhan diri beserta keluarganya baik untuk kebutuhan konsumsi maupun non konsumsi. Hal ini berkaitan pula dengan struktur ongkos usaha perikanan yang masih sangat tinggi.

Selain dimensi ekonomi, pada dimensi sosial juga masih banyak terdapat provinsi yang memiliki nilai kurang baik. Hal krusial utama yang harus dibenahi adalah pengembangan KUB pada nelayan tangkap. Sebanyak 19 Provinsi masih memiliki nilai yang buruk pada indikator pengembangan KUB nelayan. Pada dasarnya, tingkat kesejahteraan masyarakat KP sangat bergantung pada KUB tangkap karena untuk permodalan, nelayan Indonesia yang mayoritas merupakan nelayan skala kecil, sangat membutuhkan lembaga KUB sehingga masalah permodalan lebih mudah untuk diatasi. Provinsi yang harus terus meningkatkan kualitas dan kuantitas KUB perikanan tangkapnya antara lain Aceh, Sumatera Utara, Riau, Jambi, Sumatera Selatan, Lampung, DKI Jakarta, Jawa Tengah, 
Yogyakarta, Kalimantan Timur, Kalimantan Utara, Sulawesi Utara, Sulawesi Tengah, Maluku Utara dan Papua Barat. Tanpa KUB, nelayan-nelayan tersebut banyak yang akhirnya meminjam modal dengan tengkulak sehingga kesejahteraannya akan sulit meningkat. Hal ini yang menyebabkan sistem patron - client sulit untuk dihapuskan.

KUB tersebut juga nantinya akan berpengaruh pada jumlah pelaku usaha mikro yang ada di wilayah pesisir. Pemerintah harus memahami bahwa semakin banyak jumlah usaha mikro yang berkembang akan semakin baik pula tingkat kesejahteraan mereka. Usaha mikro dapat dijadikan sebagai salah satu indikator bagi keberhasilan masyarakat KP untuk meningkatkan pendapatannya. Sejauh ini terdapat 11 Provinsi dengan jumlah usaha mikro yang masih rendah.

Daerah-daerah yang memiliki potensi garam, perlu dikembangkan pula kelembagaan bagi petambak garam. Sejauh ini masih minim jumlah kelembagaan petambak garam yang bukan hanya akan berperan sebagai solusi permodalan tetapi juga akan sangat berfungsi untuk menjadi katalis harga garam sehingga tidak terlalu jatuh pada saat panen. Untuk itu, bagi provinsi yang memiliki potensi garam, wajib terus mengawal pembentukan kelembagaan garam di wilayah mereka.

Selain dari sisi kelembagaan pelaku usaha, kebijakan-kebijakan baik yang dikeluarkan pemerintah pusat maupun daerah terkait dengan keberlanjutan usaha perikanan, dibutuhkan pula penumbuhan dan pengembangan kelompok masyarakat pengawas untuk mengawal ditegakannya aturan main pengelolaan perikanan. Terdapat 10 Provinsi yang perlu ditingkatkan untuk kelembagaan pokmaswasnya (lihat Tabel 2). Tanpa adanya pengawalan dari pokwasmas, maka aturan main hanya akan mejadi aturan di atas kertas tanpa implementasi yang jelas. Penegakan hukum terhadap aturan pengelolaan suatu perairan tentunya akan sangat berpengaruh pada kesejahteraan masyarakat KP.

Aturan pengelolaan perikanan tentunya akan sangat dipengaruhi oleh revitalisasi masyarakat adat KP yang pada dasarnya menganut nilai-nilai luhur untuk keberlanjutan perairan. Revitalisasi masyarakat adat sangat berpengaruh untuk menjaga keharmonisan antara usaha perikanan dan keberlanjutan lingkungan. Tentunya dengan aturan main pengelolaan lingkungan yang baik maka akan memberikan dampak positif pula bagi pelaku usaha perikanan.

\section{Keunggulan IKMKP}

Pembangunan pada hakekatnya bertujuan untuk memperbaiki dan meningkatkan kualitas hidup manusia. Untuk mencapai tujuan tersebut, maka pembangunan perlu diimplementasikan ke dalam berbagai program pembangunan yang dapat secara langsung menyentuh masyarakat. Pembangunan memerlukan cara atau pedoman yang terarah mengenai bagaimana meningkatkan kualitas hidup manusia tersebut (Suharto, 2014). Pembangunan tersebut juga harus dilakukan pengukuran secara berkala untuk melihat seberapa besar pembangunan telah menghasilkan kesejahteraan atau kualitas hidup yang semakin tinggi. Telah banyak pendekatan untuk mengukur kesejahteraan suatu masyarakat. Menurut Sayogyo (1997), garis kemiskinan berdasarkan kebutuhan minimum rumah tangga adalah senilai $2.140 \mathrm{~kg}$ beras setiap orang per tahun di pedesaan dan $360 \mathrm{~kg}$ beras setiap orang per tahun di daerah kota. Penetapan garis kemiskinan ini yang setara dengan nilai beras dimaksudkan untuk dapat membandingkan tingkat hidup antar waktu dan perbedaan harga kebutuhan pokok antar wilayah. Pendapat Sayogyo ini pada masa berikutnya mendapat kritikan dari Both dan Sundrum, karena dalam kenyataannya beras tidak merupakan bahan kebutuhan pokok penduduk pedesaan yang miskin terutama di Pulau Jawa. Selain itu, taksiran Sayogyo masih mengundang kritik karena digunakannya data konsumsi rumah tangga dan mengalihkannya menjadi data dalam arti per kapita, yaitu dengan membaginya dengan ukuran rumah tangga rata-rata di setiap daerah. Di sini dianggap ukuran rumah tangga dalam setiap kelompok pengeluaran masyarakat adalah sama sedangkan pada kenyataannya tidak demikian (Suparta, 1997). Berarti untuk garis kemiskinan ini, kesejahteraan hanya diukur berdasarkan nilai kebutuhan pokok (beras) yang termasuk dalam indikator ekonomi.

Sedangkan tolok ukur kesejahteraan dari Badan Koordinasi Keluarga Berencana Nasional (BKKBN) dikategorikan ke dalam kelompok Pra KS 1 (Pra Keluarga Sejahtera Tahap Pertama) disebut miskin, bila lima indikator di bawah ini yang dipenuhi oleh keluarga tersebut, yakni : a). Anggota keluarga melaksanakan ibadah agama; b). Pada umumnya anggota keluarga makan dua kali sehari atau lebih; c). Anggota keluarga memiliki pakaian yang berbeda untuk di rumah, belanja/sekolah, dan bepergian; d). Bagian lantai yang terluas bukan dari tanah; dan e). Anak sakit atau pasangan usia subur ingin ber KB dibawa ke sarana kesehatan. 
Kemajuan merupakan komponen penting dalam pembangunan. Namun demikian, pembangunan bukanlah semata-mata fenomena ekonomi. Pembangunan harus ditujukan lebih dari sekedar peningkatan kemakmuran manusia secara material dan finansial. Pembangunan harus dipandang sebagai proses multi dimensional yang melibatkan reorganisasi dan reorientasi sistem ekonomi dan sosial secara menyeluruh. Disamping usaha-usaha peningkatan pendapatan secara ekonomi, pembangunan juga memerlukan perubahan struktur-struktur sosial, kelembagaan, sikap-sikap masyarakat termasuk kebiasaan dan keyakinan (Todaro dan Smith, 2003). Untuk itu, perlu memasukan komponen sosial dalam mengukur kesejahteraan suatu masyarakat yang merupakan tujuan dari setiap pembangunan. Banyak pendekatan untuk mengukur tingkat kesejahteraan hanya berdasarkan pada indikator ekonomi saja. Indeks Kesejahteraan Rakyat (IKraR) yang mulai dibentuk sebagai suatu instrumen atau alat ukur kesejahteraan masyarakat dengan memperhitungkan bukan hanya aspek ekonomi masyarakat saja. IkraR pada awalnya didasari dengan pemikiran bahwa kesejahteraan bersifat holistik, yakni kesejahteraan tidak hanya dilihat dari sudut pandang ekonomi, atau sosial, tetapi mencakup kesejahteraan ekonomi, sosial, dan politik. Setelah dihasilkan rumusan tentang konsep kesejahteraan, selanjutnya ditentukan apa yang akan diukur, dan bagaimana mengukurnya. Mengacu pada batasan kesejahteraan yang digunakan, maka pengukurannya pun ditetapkan ke dalam bentuk tiga dimensi, yakni: dimensi ekonomi, dimensi sosial, dan dimensi politik, yang kemudian dijabarkan dengan demokrasi dan governance. Berikut indikator yang terdapat dalam IKraR.

Tabel 3. Indikator IKraR

Table 3. Ikrar's Indicators.

\begin{tabular}{|c|c|c|}
\hline No & Dimensi/Dimension & Indikator/Indicator \\
\hline 1 & Keadilan Sosial / Social Justice & $\begin{array}{l}\text { Akses Listrik/ Electrical Access } \\
\text { Akses berobat/ Access to treatment } \\
\text { Rekreasi / Recreation } \\
\text { lama sekolah > usia } 15 \text { tahun / Duration of school > } 15 \\
\text { years old } \\
\text { Pemanfaatan jaminan sosial / Utilization of social security } \\
\text { Harapan hidup > } 40 \text { tahun / Life expectancy > } 40 \text { years old } \\
\text { Akses air bersih / Water Acces } \\
\text { Akses sanitasi / Sanitation acces } \\
\text { Pengeluaran perkapita > GK / Expentur per capita > GK } \\
\text { Tingkat pemerataan pendapatan / Level on income } \\
\text { distribution }\end{array}$ \\
\hline 2 & $\begin{array}{l}\text { Keadilan ekonomi / Economic } \\
\text { justrice }\end{array}$ & $\begin{array}{l}\text { Kepemilikan rumah sendiri / Asset ownership (houses) } \\
\text { Usia pekerja> } 15 \text { tahun/ Worker age > } 15 \text { years old } \\
\text { Rasio pengeluaran terhadap GK / } \\
\text { The ratio of spending on GK } \\
\text { Rasio PAD terhadap APBD / Ratio of PAD to APBD } \\
\text { Akses kepada sumber daya ekonomi / } \\
\text { Access to economic resources } \\
\text { Rasio biaya pendidikan terhadap total pengeluaran / } \\
\text { The ratio of education costs to total expenditure } \\
\text { Rasio biaya kesehatan terhadap total pengeluaran / Ratio of } \\
\text { health costs to total expenditure }\end{array}$ \\
\hline 3 & Demokrasi / Democration & $\begin{array}{l}\text { Akses informasi / Information acces } \\
\text { Rasa aman / Sense of secure } \\
\text { Kebebasan sipil / Civil liberties } \\
\text { Hak politik/ Political right } \\
\text { Lembaga demokrasi/ Democration institution }\end{array}$ \\
\hline
\end{tabular}

Sumber : Kementerian Koordinator Bidang Kesejahteraan Rakyat, 2012/ Source: Coordinating Ministry for People's Welfare, 2012 
Berdasakan indikator yang dibangun dalam IKraR, karena sifatnya yang umum, maka setiap sektor khususnya dalam kementerian tidak dapat menggunakan IkraR untuk mengukur tingkat kesejahteraan masyarakat di sektor tertentu. Contohnya, Kementerian Kelautan dan Perikanan (KKP) tidak dapat serta merta mengukur kesejahteraan masyarakat kelautan perikanan dengan hanya mengacu pada indikator IkraR. Misalnya, jika berdasarkan IkraR, dalam suatu masyarakat indikator yang kurang adalah akses air bersih atau listrik, maka KKP sebagai kementerian tidak berwenang untuk melakukan perbaikan pada sektor tersebut. Hal ini tentunya akan menyulitkan untuk melakukan peningkatan kesejahteraan masyarakat kelautan dan perikanan (KP). Diperlukan sebuah indikator yang memang menyentuh langsung masyarakat KP dan dapat langsung dikaitkan dengan program-program yang ada di Kementerian. Dari IKMKP, dapat terlihat bahwa setidaknya terdapat banyak program, tercermin dalam indikator, yang merupakan indikator kunci. Indikator-indikator kunci ini dapat dijadikan sebagai patokan bagi setiap pengambil kebijakan untuk melaksanakan program di tahun berikutnya sehingga kesejahteraan masyarakat KP dapat ditingkatkan atau dikelola nilainya dengan baik. Dengan IKMKP, pengambil kebijakan dapat mengaitkan langsung angka kesejahteraan masyarakat KP dengan program-program yang direncanakan.

\section{KESIMPULAN DAN IMPLIKASI KEBIJAKAN}

\section{Kesimpulan}

Hasil penelitian menunjukkan bahwa terdapat indikator-indikator yang harus dijadikan prioritas untuk meningkatkan kesejahteraan masyarakat KP secara cepat. Terdapat 5 indikator kunci di bidang sosial antara lain XS1 (kelembagaan usaha KUB Tangkap), XS4 (Kelembagaan usaha Garam Rakyat), XS5 (kelembagaan Pokmaswas), XS7 (masyarakat adat, tradisional dan lokal yang direvitalisasi) dan XS9 (pelaku usaha mikro yang mandiri di kawasan pesisir dan pulau-pulau kecil). Sedangkan untuk indikator kunci, terdapat 3 indikator di bidang ekonomi yaitu XE1 (Nilai Tukar Nelayan), XE8 (Rata-rata pendapatan petambak garam/bulan) dan XE11 (struktur ongkos usaha perikanan).

Penentuan indikator kunci sangat diperlukan untuk menyusun program yang akan dibuat oleh pemerintah dengan tetap mempertimbangkan aspek strategi maintenance atau improvement pada setiap provinsi. Dari 34 provinsi, terdapat 12 provinsi yang termasuk kategori maintenance sedangkan sisanya termasuk ke dalam improvement. Untuk kategori maintenance, pemerintah harus melakukan langkah peningkatan namun sifatnya hanya menjaga agar nilai indeks kesejahteraan pada tahun berikutnya tetap terjaga. Sedangkan untuk daerah-daerah dengan status improvement harus bekerja keras meningkatkan nilainya sesuai indikator kuncinya. Setidaknya terdapat 22 provinsi yang harus diwaspadai nilai indeksnya dan harus diarahkan sesuai indikator kunci untuk menyusun program di tahun berikutnya. Hal ini menunjukkan masih banyaknya pekerjaan rumah bagi pemerintah baik pusat dan daerah yang secara bersamasama harus bersinergi untuk meningkatkan level kesejahteraan masyarakat.

\section{Implikasi Kebijakan}

IKMKP memiliki kelebihan dibanding indikator kesejahteraan lainnya. Jika indikator kesejahteraan lainnya hanya berkutat pada indikator terkait rumah tangga, maka pada IKMKP dapat terlihat indikator kunci yang dapat dijadikan panduan program bagi pemerintah untuk mempertahankan nilai IKMKP suatu provinsi atau bahkan meningkatkannya. Untuk itu pemilihan penggunaan IKMKP sebagai barometer pengukur indeks kesejahteraan masyarakat kelautan perikanan sudah tepat dan harus terus dilakukan.

Kebijakan yang dilakukan oleh pemerintah baik pusat maupun daerah, sebaiknya memperhatikan indikator-indikator kunci di masingmasing daerah. Program prioritasi hendaknya disesuaikan dengan indikator kunci yang paling berpengaruh di dimensi sosial dan ekonomi. Bahkan untuk program per daerah dapat dirujuk sesuai indikator kunci yang paling berpengaruh di daerah tersebut. Jika kebijakan tidak disesuaikan dengan indikator kunci maka kemungkinan nilai kesejahteraan tidak dapat meningkat secara cepat. Indikator-indikator kunci yang telah diperoleh dari hasil penelitian ini sebaiknya dijadikan pedoman dalam rangka peningkatan kesejahteraan masyarakat kelautan dan perikanan.

Untuk indikator sosial, program-program yang harus digencarkan untuk meningkatkan nilai IKMKP dengan cepat adalah revitalisasi kelembagaan di setiap sektor usaha perikanan. Selama ini kelembagaan yang berperan penting dalam pengembangan usaha seringkali diabaikan 
atau tidak berkembang. Setidaknya pemerintah harus terus menumbuhkan aspek kelembagaan dan melakukan pendampingan sekaligus monitoring berkala untuk melihat perkembangan kelembagaan baik di usaha perikanan tangkap, budidaya garam dan pengolahan hasil perikanan. Selain itu pemerintah harus menganggap revitalisasi masyarakat adat sebagai hal krusial yang harus dilakukan karena masyarakat adatlah yang dapat digunakan sebagai garda utama untuk melakukan pengelolaan perikanan.

Sedangkan untuk indikator ekonomi, kebijakan yang dapat dilakukan oleh pemerintah terutama berkaitan dengan pendapatan dan struktur ongkos usaha perikanan tangkap. Pendapatan nelayan haruslah dapat ditingkatkan mengingat mayoritas pelaku usaha di bidang perikanan merupakan nelayan. Pemerintah juga harus tetap memperhatikan komposisi ongkos usaha perikanan dan memperhatikan bagian mana yang paling memberatkan bagi para nelayan sehingga kesejahteraan mereka dapat meningkat.

\section{UCAPAN TERIMA KASIH}

Tulisan ini merupakan bagian dari penelitian "Analisis dan Penghitungan Indeks Kesejahteraan Masyarakat Kelautan dan Perikanan (IKMKP) Tahun 2016 Serta Nilai Proyeksi 2017-2019" dengan sumber dana berasal dari DIPA BBRSEKP TA 2016. Untuk itu penulis mengucapkan terima kasih kepada Kepala BBRSEKP, Dr. Tukul Rameyo Adi yang memberikan dukungan terhadap kajian ini dan juga disampaikan terima kasih kepada rekan-rekan peneliti lingkup BBRSEKP dan para narasumber yang telah memberikan masukan yang sangat bermanfaat.

\section{DAFTAR PUSTAKA}

Badan Pusat Statistik (BPS). 2000. Indikator sosial ekonomi indonesia. Badan Pusat Statistik Indonesia. Jakarta.

Badrudin, R. 2012. Ekonomika Otonomi Daerah. Yogyakarta: UPP STIM YKPN.

Bintarto. 1989. Interaksi Desa-Kota dan Permasalahannya. Ghalia Indonesia. Jakarta.

Kementerian Koordinator Bidang Kesejahteraan Rakyat. 2012. Ikrar: Indeks Kesejahteraan Rakyat. Kementeriaan Koordinator Bidang Kesejahteraan Rakyat. Jakarta.
Mishra, R. 2000. Globalization and the Welfare State, London: McMillan.

Nasikun. 1996. Urbanisasi dan Kemiskinan di Dunia Ketiga. PT. Tiara Wacana.Yogyakarta.

Nikijuluw, V. P. H. 2001. Populasi dan Sosial Ekonomi Masyarakat Pesisir serta Strategi Pemberdayaan Mereka dalam Konteks Pengelolaan Sumberdaya Pesisir secara Terpadu. Makalah dipresentasikan pada Pelatihan Pengelolaan Pesisir Terpadu. Bogor, 29 Oktober 2001.

Peraturan Menteri Kelautan dan Perikanan No. 45 tahun 2015 tentang Perubahan Atas Peraturan Menteri Kelautan dan Perikanan Republik Indonesia Nomor 25/Permen-Kp/2015 tentang Rencana Strategis Kementerian Kelautan dan Perikanan Tahun 2015-2019.

Satria, A. 2002. Pengantar Sosiologi Masyarakat Pesisir. Pustaka Cidesindo. $130 \mathrm{Hal}$.

Sayogyo, T. 1997. Garis Kemiskinan dan Kebutuhan Minimum Pangan. LPSB-IPB. Bogor.

Suharto, E. 2014. Analisis Kebijakan Publik: Panduan Praktis Mengkaji Masalah dan Kebijakan Sosial. CV Alfabeta Bandung: Bandung.

Suparta, I. W. 1997, Analisis Mikro Ekonometrik Garis Kemiskinan di Kabupaten Aceh Besar Provinsi Daerah Istimewa Aceh, Unlversitas Syiah Kuala, Banda Aceh.

Susanto, J. dan D. H. Laksana. 2013. Uji Kausalitas antara Konsumsi Energi dan Pertumbuhan Ekonomi di ASEAN. Buletin Ekonomi Vol 11 No 1 April 2013.

Sutaryo, W. K. Jaya, S. E. Swasono, R. Baswir dan I. D. Prijambada. 2015. Membangun Kedaulatan Bangsa Berdasarkan Nilai-Nilai Pancasila: Pemberdayaan Masyarakat dalam Kawasan Terluar, Terdepan, dan Tertinggal. Pusat Studi Pancasila: Universitas Gajah Mada.

Todaro, M. P. and S. C. Smith. 2003. Pembangunan Ekonomi. Munandar H, AL Puji, penerjemah. Edisi Kesembilan. Jakarta (ID): Erlangga. Terjemahan dari: Economic Development. 